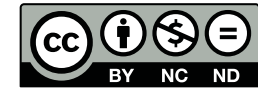

Estudos Teológicos foi licenciado com uma Licença Creative Commons Atribuição - NãoComercial - SemDerivados 3.0 Não Adaptada

http://dx.doi.org/10.22351/et.v57i1.2969

\title{
A Reforma do SÉculo XVI e suas implicaÇões Para a ATUalidade: DA PRÁTICA DA EXCOMUNHÃO AOS GESTOS DE RECONCILIAÇÃo ${ }^{1}$
}

\author{
The sixteenth century Reformation and its implications nowadays: \\ from the excommunication to reconciliation gestures
}

Elias Wolff ${ }^{2}$

\begin{abstract}
Resumo: O artigo faz uma análise da Reforma do século XVI centrado em três elementos que estão na origem das questões teológicas e pastorais do processo reformatório: a prática das indulgências, as 95 Teses de Lutero e a bula Exsurge Domine do papa Leão X. Aponta para uma nova compreensão desses elementos dentro de dois horizontes: os resultados das novas pesquisas sobre a pessoa e o ensino de Lutero; e o atual contexto do diálogo católico-luterano. A partir disso, mostra elementos da Reforma que podem ser acolhidos como herança comum para católicos e luteranos em nossos dias e pergunta pela possibilidade de uma revisão da excomunhão de Lutero, de modo a favorecer os esforços por uma comunhão na fé entre católicos e luteranos.
\end{abstract}

Palavras-chave: Igreja. Reforma. Lutero. Excomunhão. Ecumenismo.

\begin{abstract}
The article analyses the sixteenth century Reformation focusing three elements which count to the origins to the pastoral and theological matters in the Reformation process: the indulgences practice, the 95 theses, and Pope Leo X's Exsurge Domine bull. The research points out to different comprehensions on these elements on two horizons: the results of the new researches on Luther; and the current dialogue context regarding Catholics and Lutherans. Thus, the work demonstrates Reformation elements that may be received as a common heritage today. Furthermore, this paper asks about the possibility on reviewing Luther's excommunication, so that it could favor Catholics and Lutherans Faith communion efforts.
\end{abstract}

Keywords: Church. Reformation. Luther. Excommunication. Ecumenism.

\footnotetext{
1 O artigo foi recebido em 14 de março de 2017 e aprovado em 25 de abril de 2017 com base nas avaliações dos pareceristas ad hoc.

2 Doutor em Teologia e mestre em Filosofia, membro do Programa de Pós-Graduação em Teologia da PUCPR. Especialista em ecumenismo e diálogo inter-religioso, líder do Grupo de Pesquisa Teologia, Ecumenismo e Diálogo Inter-Religioso (PUCPR), coordenador da Comissão Teológica do Conselho Nacional de Igrejas Cristãs do Brasil e do Núcleo Ecumênico e Inter-Religioso da PUCPR. Bolsista produtividade CNPq. Contato: elias.wolff@pucpr.br
} 


\section{Introdução}

Os posicionamentos de Lutero sobre a teologia, a espiritualidade, a organização estrutural e a ação pastoral da igreja no século XVI, no contexto de polêmicas em torno das indulgências, levaram-no à excomunhão. Nasce a Reforma, que dá origem a diferentes tradições eclesiais, com patrimônios doutrinais isolados e em conflito. Mas pesquisas atuais constatam que nem tudo na teologia de Lutero era oposto à doutrina católica. E 500 anos depois, verificam-se mudanças significativas nas igrejas católica e luterana, de modo que não mais valem para o presente muitas das mútuas condenações doutrinais do passado. É importante, então, perguntar se da parte da Igreja Católica seria possível uma revisão do processo de excomunhão de Lutero e um gesto simbólico de levantamento daquele ato, manifestando, com isso, o sincero desejo de fortalecer os esforços por reconciliação entre católicos e luteranos.

\section{Revendo os fatos}

\section{As 95 Teses}

Lutero não admitia que a prática das indulgências, tal como praticada em seu tempo, fosse coerente com a proposta do perdão e da salvação em Cristo. Em 31 de outubro de 1517, lança 95 Teses, questionando cinco principais elementos das indulgências: 1) a natureza das indulgências: não é a reconciliação com Deus (Tese 33), pois suas graças "se referem somente às penas de satisfação sacramental, determinadas pelos seres humanos" (Tese 34), pelo que as indulgências não têm poder para perdoar pecados (Tese 76, 52). Está em questão também quais são os "tesouros da igreja" a partir do qual se pregam as indulgências: os temporais (dinheiro acumulado) (Tese 57 e 64, 66, 67), os méritos de Cristo e dos santos, que "operam sem o papa" (Tese 58 e 63), o Evangelho (Tese 62) ou os pobres (Tese 59,43). 2) A disposição do fiel para receber as indulgências: aqui Lutero vê uma dissociação entre o perdão e a contrição (Tese 35) e opõe-se à compra das indulgências pelos falecidos (Tese 13). 3) A autoridade do papa: para Lutero, o papa "não quer nem pode dispensar de quaisquer penas senão daquelas que impôs por decisão própria ou dos cânones” (Tese 5). "O papa não tem o poder de perdoar culpa a não ser declarando ou confirmando que ela foi perdoada por Deus" (Teses 6, 20, 38). 4) Questões econômicas: entende Lutero que "a maior parte do povo está sendo ludibriada" pela proposta de absolvição da pena (Tese 24), o que tem interesse econômico (Teses 50 e 51). 5) A pregação: alerta os bispos para estarem atentos ao que pregam os comissários das indulgências (Teses 51, 56, 69, 70, $72,74,75,77)$, pois não esclarecem a verdadeira doutrina da igreja (Tese 56).

Com as Teses Lutero mostra um problema mais amplo que as indulgências: o clima eclesial e espiritual da época, marcado pela devoção popular muito próxima da superstição; o antropocentrismo teológico, que se expressa sobretudo no racionalismo da escolástica; o excessivo poder das autoridades eclesiásticas. As Teses têm a fina- 
lidade de discutir essas questões, na intenção de contribuir para o esclarecimento da doutrina da igreja e para que seja feita a reforma de que tanto necessita.

\section{Exsurge Domine e Decet Romanum Pontificem}

Em resposta a Lutero, o papa Leão X publicou a bula Exsurge Domine ${ }^{3}$, condenando 41 de suas afirmações, consideradas "heréticas, escandalosas, perigosas, falsas, ofensivas" (DH 1492), que agrupamos em três blocos: I) as que dizem respeito ao sacramento da confissão e ao pecado. O papa acusa Lutero de afirmar que os sacramentos não dão a graça do perdão (1); que as partes do sacramento (contrição, confissão e satisfação) não se fundamentam nas Escrituras (5); que o pecado permanece depois da absolvição $(2,15)$; que o pecador não é capaz de uma contrição que o ajude a ser perdoado $(4,6,7,11,14)$ e crer que o perdão foi recebido vale mais que o ato da contrição, da confissão e da absolvição $(10,11,12,15)$; a impossibilidade de confessar todos os pecados $(9,10)$; e que qualquer pessoa pode conceder o perdão dos pecados (13). II) Outro conjunto de erros diz respeito às indulgências, entendendo que Lutero nega ser a sua natureza a administração pela igreja dos tesouros espirituais que ela possui (17), que não tem nenhum efeito para a remissão dos pecados $(19,18,20,21)$. III) As afirmações sobre a doutrina do papado: Exsurge Domine acusa Lutero de não reconhecer que o papa é o vigário de Cristo, por ele instituído sobre a igreja universal $(25,26)$; que o papa não tem poder para decidir sobre questões de fé, moral e boas obras (27), o que só pode ser feito por um concílio e sem a pretensão de infalibilidade $(28,29,30,33)^{4}$. Lutero tinha sessenta dias para se retratar. Como não o fez, em 3 de janeiro de 1521, Leão X o excomungou com a bula Decet Romanum Pontificem.

\section{Diálogo infrutífero}

Lutero esperava receber o apoio do papa, pois entendia estar ajudando a igreja a corrigir graves erros que a distanciavam do evangelho. Mas Roma ignorou as questões levantadas pelo monge agostiniano e com a ajuda do dominicano Silvestre Mazzolini (1457-1523) o acusou de herege. Iniciou-se uma série de debates entre Lutero e representantes do papa. Não havendo entendimento entre os debatedores, em 1520 foi redigida a já mencionada bula Exsurge Domine e enviada a Lutero, que reage queimando a bula papal e livros canônicos. Nesse clima de controvérsia, Lutero aprofunda suas doutrinas, reduzindo o número de sacramentos a Batismo, Eucaristia e Penitên-

\footnotetext{
3 PAPA LEÃO X. Bulla Exsurge Domine (15/06/1520). In: DEZINGER, Heinrich; HÜNERMANN, Peter. Enchiridion Symbolorum. Definitionum et declarationum de rebus fidei et morum. Bolonha: EDB, 1996. p. 627-635.

4 O documento de Leão X rejeita, ainda, as afirmações de Lutero que dizem ser a doutrina sobre o purgatório sem fundamento na Bíblia, e o modo como ensina sobre a condição das almas que, porventura, lá se encontram $(37,38,39,40)$. Condena o ensino do Reformador que afirmava ser a pessoa pecadora em cada ato $(31,32,35,36,40)$, que se deve dar a comunhão sob as duas espécies (16), que a excomunhão é algo a ser apreciado (24), mas "são apenas penas externas e não privam o homem das orações espirituais comuns da igreja" (23).
} 
cia (Do Cativeiro Babilônico da Igreja, 1520) ${ }^{5}$ e incluindo o perdão dos pecados no significado da Eucaristia (Um Sermão sobre o Venerabilíssimo Sacramento do Santo e Verdadeiro Corpo de Cristo e sobre as Irmandades, 1519) ${ }^{6}$; rejeita a compreensão da doutrina do mérito (Das Boas Obras, 15207); desenvolve uma nova concepção de igreja, realçando sua invisibilidade (Sobre o Papado de Roma, 1520) ${ }^{8}$, afirmando o sacerdócio universal de todos os batizados e a autoridade da Bíblia sobre qualquer outra (À Nobreza Cristã da Nação Alemã , 1520) ${ }^{9}$. Em tudo Lutero continua com a consciência de estar agindo na liberdade e coerência de sua fé: "Essa é a liberdade cristã, nossa fé [...] que ninguém necessite da lei ou de obras para a justiça e a salvação"10.

Em abril de 1521, Lutero vai à Dieta de Worms, onde lhe são mostrados os seus escritos e lhe é perguntado se afirma ou rejeita o conteúdo dos mesmos, ao que responde:

A menos que eu me convença pelo testemunho das Escrituras ou por uma razão clara [...] eu estou vinculado pelas Escrituras que citei, e minha consciência está presa à Palavra de Deus. Eu não posso e não quero retratar-me de nada, uma vez que não é nem seguro nem correto ir contra a consciência. Ajude-me Deus. Amém ${ }^{11}$.

O rompimento definitivo com Roma mostrava-se irreversível.

\title{
Atualizando a compreensão dos fatos
}

\author{
O que Lutero queria, afinal?
}

Lutero está convicto de que "ecclesia indiget reformationem" ("a igreja necessita de reformas" - introdução às Teses), o que deve acontecer em três principais âmbitos: na teologia, de caráter mais bíblico, patrístico e existencial, em contraposição ao racionalismo da escolástica; na pregação, com linguagem mais espiritual do que disciplinadora e legalista; nas estruturas da igreja. O objetivo da reforma é "re-centrar" a igreja em Cristo e no seu evangelho, afirmando o primado das Escrituras

5 LUTERO, Martinho. Do Cativeiro Babilônico da Igreja. In: LUTERO, Martinho. Obras Selecionadas. São Leopoldo: Sinodal; Porto Alegre: Concordia, 1989. v. 2, p. 341-424. [A seguir, abreviado como OSel.]

6 LUTERO, Martinho. Um Sermão sobre o Venerabilíssimo Sacramento do Santo e Verdadeiro Corpo de Cristo e sobre as Irmandades (1519). In: OSel, 1987, v. 1, p. 425-446.

7 LUTERO, Martinho. Das Boas Obras (1520). In: OSel, 1989, v. 2, p. 97-170.

8 LUTERO, Martinho. A respeito do papado em Roma contra o Celebérrimo Romanista de Leipzig. In: OSel, 1989, v. 2, p. 197-238.

9 LUTERO, Martinho. À Nobreza Cristã da Nação Alemã, acerca da Melhoria do Estamento cristão. In: OSel, 1989, v. 2, p. 289.

${ }^{10}$ LUTERO, Martinho. Tratado de Martinho Lutero sobre a Liberdade Cristã. In: OSel, 1989, v. 2 , p. 441.

11 LUTERO, Martinho. Discurso pronunciado na Dieta de Worms - Testemunho. VV.AA. Martin Luther, 450 ans de Réforme. Internationes, 1967. p. 56. "A moins qu'on ne me convainque (autrement) par dês attestations de 1'Ecriture ou par d'évidente raisons ... jê suis lié par les textes scripturaires que j'ai cites et ma conscience est captive dês paroles de Dieu; je ne puis ni ne veux me rétracter en rien car il n'est ni sûr ni honnête d'agir contre sa propre conscience. Que Dieu me soit en aide. Amen”. 
na vida cristã. A base é a afirmação da justificação unicamente por graça e fé em Cristo (Rm 1.17), sustentada nos princípios sola fide, sola gratia, sola Scriptura. A reforma deve ser ampla e profunda: "Uma reforma na Igreja é impossível se não se arrancam até a raiz os cânones, os decretais, a teologia escolástica, a filosofia, a lógica"12. Então Lutero passa a contestar o aparato canônico da igreja, o sacerdócio hierárquico, o institucionalismo eclesiástico e o seu corpo doutrinal. Mas ele não queria dividir a igreja. Mesmo no clima mais duro das controvérsias, entendia-se unido ao papa e defendendo a doutrina: "Com isto nada queremos dizer nem acreditamos ter dito qualquer coisa

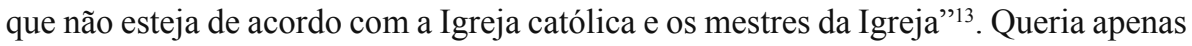
reformar a igreja e o fez, "embora com erros e equívocos"14. Observou que "a Igreja romana, outrora a mais santa de todas, se transformou [...] no lupanar mais impudente de todos"15. Por isso: "A Igreja necessita de uma reforma, o que não é tarefa de uma única pessoa, do pontífice, nem de muitos cardeais - como o provou, a ambas as coisas, o último concílio -, mas de todo o mundo, mais ainda: unicamente de Deus"16. As dificuldades do diálogo e as animosidades se acentuam a ponto de Lutero acusar o papado de "anticristo". As discussões inicialmente sobre doutrina incluem agora as estruturas da igreja. O distanciamento de Roma é inevitável:

Visto que o papa juntamente com os seus simplesmente se nega a realizar um concílio, não querendo reformar a Igreja nem acrescentar qualquer progresso ou remediar, e sim querendo que a Igreja vá à ruína [...] nada podemos fazer, e temos que [...] buscar conselho e ajuda em outra parte e, antes de tudo, buscar e pedir uma reforma junto a nosso Senhor Jesus Cristo ${ }^{17}$.

Depois do encontro que Lutero e Andreas Bodenstein von Karsltadt tiveram com Iohannes Eck em Leipzig (1519), Lutero conquistou pensadores humanistas, que o ajudaram no desenvolvimento de suas Teses, e alguns nobres que lhe ofereceram proteção. Graças à imprensa de Gutenberg, os textos de Lutero logo ganham a Europa. Desse modo, o processo reformatório atinge dimensões e uma complexidade tal que escapa do controle dos teólogos reformadores.

12 Carta de Lutero a Jodocus Trutfetter, em 09/05/1518. Apud CONGAR, Yves. Lutero, la Fede, la Riforma. Brescia: Morcelliana, 1984. p. 40. "Una riforma della Chiesa è impossibile se non si svellono fino alla radice i canoni, le decretali, la teologia scolastica, la filosofia, la lógica."

${ }^{13}$ LUTERO, Martinho. Debate sobre a Teologia Escolástica. OSel, 1987, v. 1, p. 20. Lutero entendia-se vinculado à autoridade eclesiástica do seu tempo, como se verifica no texto Martinho Lutero saúda Leão X, Pontifice Romano, em Cristo Jesus, nosso Senhor. Amém. In: OSel, 1989, v. 2, p. 426-433.

${ }^{14}$ COMISSÃO INTERNACIONAL CATÓLICO-LUTERANA (CICL). Do Conflito à Comunhão. Comemoração Conjunta Católico-Luterana da Reforma em 2017. São Leopoldo: Sinodal; Brasília: CNBB, 2015. n. 222,

${ }^{15}$ LUTERO, Martinho. Do Cativeiro Babilônico da Igreja. In: OSel, 1989, v. 2, p. 423.

${ }^{16}$ LUTERO, Martinho. Explicações do Debate sobre o Valor das Indulgências. Tese 89. In: OSel, 1987, v. 1, p. 188.

${ }^{17}$ LUTERO, Martinho. Dos Concílios e da Igreja. In: Osel, 1992, v. 3, p. 306. 


\section{Um balanço das controvérsias}

$\mathrm{Na}$ história das relações entre católicos e luteranos, as doutrinas de uns e de outros foram interpretadas como mutuamente excludentes, pois olhadas apenas no contexto polêmico no qual foram escritas. $\mathrm{Na}$ atualidade, observam-se, felizmente, significativas mudanças em ambas as partes, explicitando convergências e, inclusive, consensos na fé das duas tradições.

\section{Reconhecimento da catolicidade da fé em Lutero?}

Lutero entendia que o seu ensino teológico não negava a fé católica, mas ajudava na superação de riscos que a ameaçavam, tanto na formulação conceitual quanto na sua aplicação prática, o que levou Joseph Lortz a concluir que "Lutero superou em si mesmo um catolicismo que não era inteiramente católico"18. Há que se reconhecer em Lutero afirmações de verdadeira fé. Concentrando-nos nas 95 Teses, apontamos para: as que tratam do sacramento da penitência (especificamente as teses de 1 a 3); sobre o costume antigo de dar a pena antes da absolvição (12); a igualdade entre papa, bispos e padres no poder do perdão sacramental (25); a crítica do caráter comercial das indulgências $(27,28,50,51,66,67,73)$; a dificuldade, dada a pouca formação dos fiéis, de entender a autenticidade tanto do penitente quanto da aquisição da indulgência (31); a crítica a quem acredita ter na carta de indulgência total segurança da salvação (32 e 52); a identificação do documento de indulgência com o perdão de Deus (33); a necessidade da contrição para se obter o perdão (35); que, na via prática, as indulgências podem relaxar a contrição (40), a prática da caridade (41) e as obras de misericórdia (42); a liberdade para adquirir ou não as indulgências (47); a dificuldade de entender os verdadeiros tesouros da igreja $(56,57,59,62)$; a necessidade de rever a pregação das indulgências ( 69 a 80), evitando desvios da doutrina sobre a mesma (50, $51,91)$; a pertinência dos questionamentos populares sobre as indulgências (80 a 89).

Esse elenco é limitado e não pretende mostrar a natureza de cada tese. Mostra, no entanto, que a minoria delas é, realmente, inadmissível na doutrina católica. Estudos atuais sobre Lutero permitem uma compreensão comum de muitas das suas posições e das problemáticas de fundo da Reforma. A consciência do caráter historicamente condicionado das formulações teológicas admite formas diferentes de apresentar o evangelho. E "não se pode culpar a alguém por seguir sua consciência quando foi formada pela Palavra de Deus e alcançou seu juízo após deliberação séria com outras pessoas"19. O que Lutero pretendia era ajudar "aqueles cuja consciência sofria sob o império da lei e das prescrições humanas, os que eram atormentados pela sua deficiência e pela preocupação da sua salvação eterna, (esses) graças à fé no evangelho podiam reaver a confiança na promessa libertadora da graça de Deus" ${ }^{\prime 2}$.

\footnotetext{
18 Apud CICL, 2015, n. 21.

19 CICL, 2015, n. 232.

${ }^{20}$ CICL. "Martin Lutero testimone di Gesù Cristo". Bolonha: EDB, 1994a, n. 9. "Coloro le cui coscienze soffrivano sotto l'imperio della legge e delle prescrizione umane, coloro che erano tormentati delle loro
} 
Essa conclusão situa-nos em dois principais elementos: na compreensão da pessoa de Lutero como "uma personalidade profundamente religiosa" do Evangelho, mestre na fé, arauto de uma renovação espiritual" 22 , que se manifestava pelo desejo de reforma e de unidade da igreja; e no reconhecimento da catolicidade do Reformador. De fato, até chegar o período polêmico da Reforma, Lutero afirmava: "me senti vinculado com as leis papais e com as tradições dos Padres, observando-as com todo zelo e fervor" ${ }^{\prime 2}$. Nas críticas que fazia à igreja, Lutero não entendia negar a sua identidade católica, mas cria estar ajudando a igreja a viver a sua catolicidade: "O primeiro protestante foi, em contrapartida, muito mais católico que grande número de seus adversários romanos" 24 .

\section{Reconhecimento da fé luterana em afirmações da Exsurge Domine?}

Semelhante exercício pode ser feito sobre os erros de Lutero apontados na $E x$ surge Domine, verificando o que também os luteranos poderiam admitir como verdade da doutrina cristã no documento papal. Destacamos: a Exurge Domine acusa Lutero de não crer na possibilidade de uma plena contrição $(4,6,12,14)$; de Lutero negar a possibilidade de confessar todos os pecados considerados graves $(8,9)$; de ensinar de que as indulgências não são a dispensação dos tesouros da igreja, os méritos de Cristo e dos santos (17); de negar que a excomunhão priva os fiéis dos bens espirituais que a igreja poderia lhe oferecer (23); de negar o poder que o papa tem para decidir sobre artigos de fé, moral e boas obras (27); de afirmar que qualquer um pode desaprovar as decisões e a autoridade dos concílios da igreja (29); de ensinar que o justo peca em toda boa obra $(31,32,35)$, pois não há livre-arbítrio (36); de afirmar que as almas dos falecidos (no purgatório) pecam por desejarem o descanso (no céu) (39), e as que saíram do purgatório pelo sufrágio dos vivos não são felizes (40); de afirmar que seria oportuno que os prelados destruíssem as bolsas de mendicância (41).

Em que a condenação dessas afirmações de Lutero estaria atingindo as convicções das igrejas luteranas na atualidade? Podem os luteranos hoje concordar com a bula papal que afirma existirem erros nesses ensinamentos de Lutero, sem com isso se sentir prejudicados na sua doutrina?

\section{Da discussão ao diálogo}

O processo que levou Lutero à excomunhão foi marcado por ambivalências. "Ele e o público [...] esperavam um intercâmbio de argumentos. Havia sido prometido um processo justo a Lutero. No entanto, ainda que lhe tivesse sido assegurado que

\footnotetext{
deficienze e dalla preoccupazione verso la loro salvezza eterna, grazie alla fede nell'evangelo potevano riavere fiducia nella promessa liberante della grazia di Dio."

${ }^{21}$ WILLEBRANDS, Johannes. Conferência na V Assembleia da Federação Luterana Mundial. La documentation Catholique, n. 1569, p. 766, 06/09/1970.

${ }^{22}$ CICL, 1994a, n.4.

${ }^{23}$ Apud STAUFER, Richard. La Reforma. Barcelona: Oikos; Tau Ediciones, 1974. p. 12.

${ }^{24}$ STAUFER, 1974, p. 25.
} 
seria ouvido, repetidas vezes recebeu a mensagem de que ou deveria retratar-se ou seria declarado herege. ${ }^{" 25} \mathrm{~A}$ indisponibilidade para compreender o real conteúdo das afirmações de Lutero impossibilitou a compreensão das suas verdadeiras intenções.

Também os luteranos admitem dificuldades no diálogo:

[...] também nós congregações e cristãos luteranos reconhecemos que os julgamentos dos reformadores nos confrontos com a Igreja Católica Romana e a teologia do seu tempo, frequentemente não eram livres de deformações polêmicas, que em parte prolongam os seus efeitos até o presente. Lamentamos sinceramente que os nossos irmãos católicos romanos tenham sido ofendidos e mal entendidos por causa de tais visões polêmicas ${ }^{26}$.

Portanto a divisão aconteceu "não sem culpa de um e de outro lado" (Unitatis redintegratio, 3). O papa João Paulo II assim se pronunciou: "Não queremos julgar uns aos outros ( $\mathrm{Rm} 14.13)$. Mas queremos reconhecer juntos a nossa culpa. Isso vale também para a graça da unidade: 'Todos pecaram' (Rm 3.23). Devemos ver e dizer isso com toda a seriedade e tirar daí as nossas consequências"27. E o papa Francisco, tratando da viagem que faria a Lund, Suécia, em 31 de outubro de 2016, para a abertura das comemorações dos 500 anos da Reforma, se pronunciou sobre Lutero: "Talvez os métodos estavam equivocados. Mas a igreja não era modelo a ser imitado [...]. Ele contestou. E deu um passo à frente para criticá-la. Depois, viu que não estava mais sozinho" 28 .

Estudos atuais constatam que muitas teses de Lutero só foram objeto de condenação porque "tomadas fora de seu respectivo contexto" 29 . Então é de se perguntar: se as teses fossem consideradas em seu contexto específico, seriam passíveis de condenação? Podemos concluir que foram rejeitadas porque não foram interpretadas em seu universo semântico próprio e, portanto, a condenação sofrida não foi justa?

De outro lado, Lutero também criticou e condenou duramente a doutrina, as estruturas, a espiritualidade e a ação pastoral da igreja do seu tempo. Mas significativas e profundas mudanças aconteceram na igreja católica desde então, de modo que muitas dessas críticas e condenações não valem para hoje. Há um clima propício para o diálogo e "[n]ão é adequado continuar repetindo antigos relatos da Reforma, que apresentam as perspectivas luteranas e católicas de forma separada e muitas vezes em

${ }^{25}$ CICL, 2015, n. 46.

${ }^{26}$ CICL. "L'unità davanti a noi”. CICL, 1994b, n. 52. “...anche noi congragazioni e cristiani luterani riconosciamo che il giudizio dei riformatori nei confronti della Chiesa cattolica romana e la teologia del loro tempo spesso non erano liberi da deformazioni polemiche, che in parte prolungano i loro effetti fino ao presente. Ci rincresce sinceramente che i nostri Fratelli cattolici romani siano stati offesi e fraintesi a causa di tali visioni polemiche."

27 Apud CICL. "L'unità davanti a noi”. CICL, 1994b, n. 51. “"Tutti hanno peccato' (Rm 3,23). Dobbiamo vedere e dire cio in tutta serità e tirarne le nostre conseguenze."

${ }^{28}$ Entrevista concedida no avião quando retornava de sua visita pastoral à Armênia, em junho de 2016. Disponível em: <http://www.ihu.unisinos.br/556972-qas-intencoes-de-lutero-nao-estavam-equivocadasq-a-opiniao-dos-protestantes>. Acesso em: 05 ago. 2016.

${ }^{29}$ CICL, 2015, n. 50. 


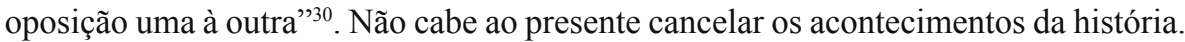
Mas pode-se rever o seu significado e trabalhar as suas consequências para hoje: "O que aconteceu no passado não pode ser mudado, mas o que e como é lembrado, com o passar do tempo, de fato muda [...] Não se trata de contar uma história diferente, mas de contar a história diferentemente" ${ }^{\prime 1}$.

Tal é o esforço do atual diálogo católico-luterano. São revisadas as questões eclesiológicas, a teologia dos sacramentos, o ministério pastoral, o ministério petrino, a espiritualidade, a missão etc. Convergências e consensos significativos são obtidos por esse diálogo, como demonstra a Declaração conjunta sobre a justificação (1999 - o Concílio Mundial Metodista a assinou em 200632). Cancelam-se as mútuas acusações de heresia, considerando a justificação por graça e fé em Cristo como a essência da identidade cristã de católicos e luteranos. Questões que permanecem não comprometem o acordo de base entre as igrejas.

\section{O reconhecimento da herança comum da Reforma}

Pelo considerado acima, justifica-se o fato de católicos e luteranos estarem hoje em condições de uma comemoração conjunta dos 500 anos da Reforma. Cresce a consciência de pertença a um mesmo corpo, o que se compreende como uma "possibilidade impossível e fonte de grande sofrimento" ${ }^{\text {"33 }}$, pelas dificuldades de convivência na plena comunhão. Reconhecer o que os une em Cristo é motivo de alegria; e o que divide faz sofrer e exige perseverança no diálogo reconciliador.

Fundamental é o entendimento comum que:

Os apelos de Lutero à reforma da igreja, isto é, à penitência, são ainda válidos para nós. Ele nos exorta a re-escutar o evangelho, a reconhecer a nossa infidelidade ao evangelho e a testemunhá-lo de maneira crível. Atualmente, isso não pode acontecer sem uma atenção recíproca entre as igrejas e ao seu testemunho, sem uma busca da reconciliação e sem abandonar os estereótipos polêmicos ultrapassados ${ }^{34}$.

${ }^{30}$ CICL, 2015, n. 8.

${ }^{31}$ CICL, 2015, n. 16.

${ }^{32}$ CICL. Declaração Conjunta sobre a Doutrina da Justificação. São Leopoldo: Sinodal; Brasília: CONIC; São Paulo: Paulinas, 1999. Essa Declaração resolveu muitos dos impasses doutrinais presentes tanto nas Teses de Lutero como na bula Exsurge Domine e no desenvolvimento teológico posterior das duas igrejas. É notável a base bíblica comum para entender a justificação (CICL, 1999, n. 8-12) e o "consenso diferenciado" sobre a justificação unicamente por graça e fé em Jesus Cristo (n. 15). São superadas as polêmicas sobre o princípio sola fides (CICL, 1999, n. 26-27), a cooperação (CICL, 1999, n. 20-21), a compreensão de mérito (CICL, 1999, n. 38-39), o simul iustus et peccator (CICL, 1999, n. 29-30).

${ }^{33}$ CICL, 2015, n. 223.

${ }^{34}$ CICL, 1994a, n. 6. "Gli appelli di Lutero alla riforma della chiesa, cioè alla penitenza, sono tuttora validi per noi. Egli ci esorta a riascoltare il Vangelo, a riconoscere la nostra infedeltà al Vangelo e a testimoniarlo in maniera credibile. Attualmente cio non può avvenire senza uma attenzione recíproca fra le chiese e la loro testimonianza, senza uma ricerca della riconciliazione e senza abbandonare gli stereotipi polemici sorpassati." 
Não se trata de reconhecer que tudo foi positivo na Reforma. Estudos de luteranos atuais expressam uma "consciência dos lados obscuros de Lutero e da Reforma"35, como os seus limites pessoais, os seus excessos polêmicos, as suas "posições viciadas e degradantes" 36 em relação aos judeus, aos anabatistas, ao levante dos colonos, ao papa. Mas isso não impede de reconhecer no Reformador

as suas razões em tentar reformar a teologia e os abusos existentes na igreja dos seus tempos, e que a sua concepção reformadora fundamental, sobre a justificação que nos é dada por Cristo sem nenhum mérito da nossa parte, não está de modo algum em contradição com a genuína tradição católica assim como se expressa, por exemplo, em Agostinho e Tomás ${ }^{37}$.

\section{Assim se pronunciou o papa Bento XVI sobre Lutero:}

O que sempre ocupava [Lutero] era a questão de Deus, era sua paixão profunda e sua força condutora de toda a sua vida. "Como posso encontrar um Deus misericordioso?", essa questão lhe apertava o coração e se constitui no fundamento de todas as suas buscas teológicas e suas lutas interiores. Para ele, a teologia não era meramente uma busca acadêmica, mas a luta por si mesmo, que por sua vez era a luta com Deus. "Como posso encontrar o Deus da graça?" O fato de que essa questão foi a força condutora de toda a sua vida nunca deixa de me impressionar. Quem atualmente ainda está preocupado com isso hoje - mesmo entre cristãos? O que representa a questão de Deus em nossas vidas? Em nossa pregação? A maioria das pessoas, mesmo cristãs, parte hoje da pressuposição de que Deus, fundamentalmente, não está interessado em nossos pecados e virtudes ${ }^{38}$.

E o papa Francisco concorda que “'[p]recisamente 'a questão sobre Deus', sobre 'o modo como podemos ter um Deus misericordioso' constituía 'a profunda paixão, a mola da vida e de todo o itinerário' de Lutero". E conclui: "No fundo, o que animava e inquietava os reformadores era indicar o caminho para Cristo. É isso que nos deve preocupar hoje, depois de termos novamente empreendido, graças a Deus, um caminho comum"39.

É assim fortalecida a orientação do Vaticano II: “É mister que os católicos reconheçam com alegria e estimem os bens verdadeiramente cristãos, oriundos de um patrimônio comum, que se encontram nos irmãos de nós separados" (Unitatis redin-

35 CICL, 2015, n. 229.

36 CICL, 2015, n. 229.

${ }^{37}$ CICL, 1994a, n. 22. "Le sue ragioni nel tentare di riformare la teologia e gli abusi esistenti nella chiesa dei suoi tempi e che e che la sua concezione firmormatrice fondamentale, sulla giustificazione che ci viene data da Cristo senza alcun merito da nostra parte, non è in alcun modo in contradizione con la genuína tradizione cattolica cosi come viene espressa, all'incirca, da sant'Agostino e da Tommaso d'Aquino."

38 PAPA BENTO XVI. Discurso aos representantes do Conselho da Igreja Evangélica na Alemanha, em 23/09/2011. Disponível em: <http://w2.vatican.va/content/benedict-xvi/pt/speeches/2011/september/ documents/hf_ben-Xvi_spe_20110923_evangelical-church-erfurt.html>. Acesso em: 09 ago. 2016.

39 Discurso à delegação ecumênica da Igreja Evangélica na Alemanha: Disponível em: <http://w2.vatican. $\mathrm{va} /$ content/francesco/pt/speeches/2017/february/documents/papa-francesco_20170206_chiesa-evangelica. html>. Acesso em: 23 fev. 2017. 
tegratio, 4). De fato, em muitos ensinamentos do Concílio Vaticano II verifica-se uma profunda sintonia com as intuições de Lutero, como: o primado das Escrituras na vida da igreja (Dei verbum), a igreja compreendida como povo de Deus (Lumen gentium, cap. II), a constante necessidade de reforma na igreja (Lumen gentium 8, UR 6), a confissão da cruz de Cristo na vida cristã e eclesial (Lumen gentium 8, UR 4, Gaudium et spes 37), os ministérios como serviço (Christus Dominus 16; Presbiteroroum ordinis), o sacerdócio comum dos batizados (Lumen gentium 10-11; Apostolicam actuositatem 2-4), a liberdade de consciência e de fé (Dignitatis humanae) ${ }^{40}$.

Assim, ao mesmo tempo em que "luteranos e católicos experimentam dor a respeito das falhas e desvios, culpa e pecado nas pessoas e eventos que são lembrados" ${ }^{\text {" }}$, podem também dizer: "na realidade do único Batismo que nos torna irmãos e irmãs, e na escuta comum do Espírito numa diversidade já reconciliada, nós sabemos valorizar os dons espirituais e teológicos que recebemos da Reforma"42. Há um "patrimônio comum" que precisa ser reconhecido (Unitatis redintegratio 3; Lumen gentium 15) como base da consciência de pertença ao mesmo corpo de Cristo e dos esforços pela superação das divisões.

\section{A revisão da excomunhão de Lutero}

Considerando o que foi refletido até aqui, cabe nos concentrarmos agora no tema da excomunhão de Martinho Lutero. A excomunhão era uma prática comum de Roma, nem sempre, porém, com motivos unicamente religiosos. ${ }^{43} \mathrm{Em}$ nossos dias, muitos entendem que "chegou o momento de eliminar a aresta que existe entre católicos e protestantes, lembrando que muitas comissões ecumênicas já concluíram que a excomunhão de Lutero foi 'teologicamente injustificável'”, como disse a pastora Margot Kässmann ao papa Bento XVI. ${ }^{44} \mathrm{~A}$ aspiração não é nova. Em março de 1963, Wilhelm Michaelis, teólogo alemão luterano, enviou ao cardeal Agostinho Bea, então presidente do Secretariado para a União dos Cristãos, uma Proposta para o melhoramento dos contatos ecumênicos, sugerindo a anulação das excomunhões de Fócio (patriarca de Constantinopla entre 858 e 867 e, novamente, entre 877 e 886),

${ }^{40}$ Esses textos do Concílio Vaticano II encontram-se em Documentos do Concílio Vaticano II. São Paulo: Paulus, 2007.

${ }^{41}$ CICL, 2015, n. 229.

${ }^{42}$ Discurso à delegação ecumênica da Igreja Evangélica na Alemanha: Disponível em: <http://w2.vatican. $\mathrm{va} /$ content/francesco/pt/speeches/2017/february/documents/papa-francesco_20170206_chiesa-evangelica. html>. Acesso em: 23 fev. 2017.

${ }^{43}$ É o que demonstram as excomunhões dos imperadores Henrique IV e Frederico II, da rainha Elizabeth I, de Napoleão, do rei Vitorio Emanuel II, entre outros casos. Inclusive toda a República de Veneza, com os seus cidadãos, já foi excomungada pelo papa, como também os membros do Partido Comunista (1949). Ver: MANCUSO, Vito. "A excomunhão como arma contra a heresia criminosa”. Revista IHU-Online. Disponível em: $<$ http://www.ihu.unisinos.br/noticias/532584-a-excomunhao-como-arma-contra-a-heresia-criminosa-artigo-de-vito-mancuso>. Acesso em: 09 ago. 2016.

44 "Luteranos sugerem a Bento XVI que revogue a excomunhão do reformador Lutero". Disponível em: $<$ http://www.metodista.org.br/luteranos-sugerem-a-bento-xvi-que-revogue-a-excomunhao-do-reformador-lutero>. Acesso em: 26 ago. 2016. Parte superior do formulário. 
Miguel Cerulário (patriarca de Constantinopla entre 1043-1054) e Lutero. ${ }^{45}$ No último período do Concílio Vaticano II, a Proposta foi enviada a 70 padres conciliares. Tratando de Lutero, o documento pedia que fossem anuladas as bulas Exsurge Domine e Decet Romanum Pontificem, a que o bispo Helmut Hermann Wittler (Osnabrück, na Saxônia) respondeu que a Exsurge Domine não poderia ser anulada, pois, mesmo que algumas condenações doutrinais de Lutero estejam em dúvida, o Concílio de Trento também as condenou. Então seria necessário rever também o Tridentino. O bispo acrescenta, porém, que "fundamentalmente nada impediria a anulação da própria bula de excomunhão, Decet Romanum Pontificem" ${ }^{\text {"46 }}$. A questão é se é possível no presente desfazer um ato de tamanha magnitude realizado no passado, ou se esse ato obrigatoriamente se perpetua na história. Mas chega-se hoje a um "quase total acordo em afirmar que a autoridade que pronunciou a excomunhão contra Lutero é competente para anulá-la" ${ }^{" 47}$. Esse ato precisa ter a competência jurídica para a análise do fato e do direito, com um novo exame das razões teológicas e históricas do processo de excomunhão de Lutero.

Em 1967, o autor da Proposta a enviou ao papa Paulo VI, com uma petição para que formasse uma comissão de canonistas, teólogos e historiadores para estudarem a questão. Em 1968, Roger Schutz encaminhou a mesma petição à Sagrada Penitenciária. ${ }^{48} \mathrm{Na}$ visita da delegação da Federação Luterana Mundial ao Secretariado para a União, em 1969, tratou-se da anulação da excomunhão de Lutero, e o secretário da Federação, Harding Meyer, "perguntava se seria imaginável, factível e desejável para uma e outra parte que, em ocasião especial, algum alto representante da Igreja Católica expressasse o que é que ela pensa atualmente acerca da pessoa e da obra de Martinho Lutero"49. Em 1971, foi encaminhado ao sínodo das dioceses da República Federal da Alemanha o pedido de algum ato que "testemunhasse diante da Igreja universal que os católicos alemães, não obstante as diferenças existentes nalgumas questões doutrinais, não acham mais o reformador Martinho Lutero digno da excomunhão" 50 . Como tal não ocorreu, os católicos de Worms e Mogúncia escreviam ao papa, sugerindo que, por ocasião dos 450 anos da dieta de Worms, ele "pronunciasse uma palavra clara acerca da pessoa e doutrina de Martinho Lutero à luz do pensamento católico contemporâneo"51. O cardeal Willebrands respondeu, em 14 de julho de 1971, que esse pronunciamento já fora feito por ele mesmo no plenário da Assembleia da Federação Luterana Mundial, em Evian/França, 1970. Questiona-se quem deve tomar a iniciativa de pedir ao papa a anulação da excomunhão de Lutero, se cristãos luteranos ou católicos. Alguns entendem que "esse é um problema da igreja católica"; outros, que também os luteranos podem fazer a proposta. Na verdade, a ex-

\footnotetext{
${ }^{45}$ MICHAELIS, Wilhelm. Controvérsias sobre a anulação da excomunhão. Concilium, v. 8, p. 95-110, 1976.

${ }^{46}$ MICHAELIS, 1976, p. 97.

${ }^{47}$ MICHAELIS, 1976, p. 98.

48 MICHAELIS, 1976, p. 100.

49 MICHAELIS, 1976, p. 101.

${ }^{50}$ MICHAELIS, 1976, p. 103

${ }^{51}$ MICHAELIS, 1976, p. 103.
} 
comunhão deixou de existir com a morte do Reformador. Mas quem estuda a pessoa e o pensamento de Lutero à luz das novas pesquisas históricas e teológicas em perspectiva ecumênica conclui que um gesto simbólico que indique levantar a excomunhão terá um profundo significado no caminho da reconciliação entre as duas igrejas.

\section{No caminho jurídico e teológico}

É inegável a convivência positiva, o intercâmbio teológico e espiritual, a cooperação pastoral entre católicos e luteranos em nossos dias. Mas isso, por mais relevante que seja, não é suficiente para desfazer a excomunhão. A excomunhão foi um ato jurídico, e por isso deverá ser desfeita com outro ato jurídico, expressando uma palavra oficial, formal, liberatória. Tal foi o que aconteceu na anulação das excomunhões de 1054 pelo papa Paulo VI e o patriarca Atenágoras (07/12/1965). É preciso um exame jurídico da excomunhão, verificando a legitimidade da pena aprovada, que pode ser questionada, entre outros: porque ela se fundamenta nas 41 teses reprovadas, e a atual reinterpretação delas esclarece que nem todas contradizem a doutrina católica; a dúvida quanto aos princípios da imparcialidade e equidade exigidos dos juízes que ouviram Lutero; a clareza que hoje se tem que Lutero não queria abandonar ou dividir a igreja, tendo, em muitas situações, sido forçado a ir a extremos que levaram à separação. ${ }^{52}$

Considerando que ao publicar as 95 Teses Lutero tinha ciência de não ter um posicionamento fechado, mas estar propondo um debate público, acadêmico, que nunca aconteceu, de modo que não pôde fazer-se compreendido em seu verdadeiro entendimento das mesmas; que os estudos atuais sobre Lutero não negam a seriedade de suas motivações de fé, pelo contrário, reconhecem nele "pessoa profundamente religiosa, que lutou com honestidade e dedicação pela mensagem do evangelho" ${ }^{53}$; que o atual diálogo entre católicos e luteranos permite verificar consensos em doutrinas fundamentais das duas igrejas, entre outros, não são as propostas pelo levantamento da excomunhão de Lutero que precisam de justificação, mas os posicionamentos que buscam mantê-la.

\section{Excomunhões do passado, válidas para hoje?}

É preciso verificar se as históricas condenações formais e recíprocas das doutrinas católica e luterana não ocorreram a partir de preconceitos comumente difundidos e que passaram a moldar a consciência dos fiéis. Elementos de caráter cultural e costumes localizados podem ter contribuído para o não entendimento do pensamento teológico do outro. Nos contextos de apologia polêmica que impregnava os debates teológicos, era notória a falta de serenidade e lucidez. Assim, apresenta-se hoje a ne-

\footnotetext{
52 MICHAELIS, 1976, p. 107.

${ }^{53}$ CICL, 1994a, n. 23. "persona profundamente religiosa che lottò con onestà e dedicazione per il messagio dell'Evangelo."
} 
cessidade de uma profunda revisão das condenações afirmadas em tais contextos para verificar se elas mantêm seu fundamento para os tempos atuais.

Além disso, há também mudanças ocorridas nas igrejas católica e luterana. Se não há alterações quanto ao conteúdo da fé, é visível o redimensionamento na sua formulação. E isso não é pouco. A forma de uma igreja expressar sua convicção de fé nem sempre foi compreendida pela outra, o que levou a distanciamentos por se entender que não apenas falavam uma linguagem diferente sobre a fé, mas que essa fé em si mesma era diferente. Assim, por exemplo, os teólogos da Reforma do século XVI acusavam a Igreja de Roma de pelagiana, pois estaria incentivando a amar a Deus e cumprir os seus mandamentos com o próprio esforço ${ }^{54}$; que os sacramentos justificam ex opere operato, sem a necessidade da boa disposição de quem o recebe ${ }^{55}$; ou que o sacrifício da missa nega o valor e a unicidade do sacrifício na cruz $^{56}$. A doutrina católica, por sua vez, acusou os teólogos da Reforma de negarem o valor dos dez mandamentos para a vida cristã (DH 1659); de afirmarem que o que foi justificado não pode mais pecar nem perder a graça (DH 1573); de ensinarem que os sacramentos não concedem a graça ex opere operato, sendo suficiente a fé para se obter a promessa de Deus (DH 1608); de negarem a presença real de Cristo na Eucaristia (DH 1651), por rejeitarem a doutrina da transubstanciação (DH 1652).

O fato é que no contexto de polêmica uma igreja não conseguiu expressar claramente a sua verdade nem compreender o que a outra afirmava. Uns e outros confundiram linguagem e conteúdo da fé. Assim, por exemplo, a forma de se entender a presença real causou controvérsias; a concentração da vida eclesial no ministro ordenado levou a confusões sobre o sacramento da Ordem; diferenças na vida cristã esconderam o valor do Batismo comum; e a doutrina da justificação pareceu o pilar apenas da igreja luterana. Avanços no diálogo constatam hoje o conteúdo comum da fé nesses e em outros elementos, mesmo se usando linguagens diferentes. A doutrina luterana afirma que na Ceia "os elementos consagrados não permanecem simplesmente pão e vinho, mas em virtude da palavra criadora nos são dados como corpo e sangue de Cristo", pelo que se afirma uma "transformação" nas espécies consagradas, ainda que não se utilize o conceito da transubstantiatio ${ }^{57}$; que "não rejeita, em linha de princípio, de aplicar o conceito de sacramento ao ministério e à ordenação [...] com o ato da ordenação o Espírito Santo, comunicando a graça, habilita o ordenado a cumprir o seu ministério"58; o mútuo reconhecimento do Batismo é um fato consumado; sobre a justificação, as igrejas afirmam juntas:

${ }^{54}$ A CONFISSÃO DE AUGSBURGO, art. 18.

${ }_{55}$ A CONFISSÃO DE AUGSBURGO, art. 13.

${ }_{56}^{56}$ ARTIGOS DE ESMALCALDA, II, 2; A CONFISSÃO DE AUGSBURGO, art. 24.

${ }^{57}$ Cf. CICL. La cena del Signore. Enchiridion Oecumenicum. Bolonha: EDB, 1994c. v. 1, n. 51 . O diálogo permite também a católicos e luteranos afirmarem juntos a "eucaristia como sacrifício de ação de graças pelo sacrifício da cruz presente no sacramento" (CICL, 1994c, n. 60), sem significar repetição ou carência no valor salvífico do único sacrifício de Cristo na cruz.

${ }^{58}$ CICL. Vie verso la comunione. Enchiridion Oecumenicum. Bolonha: EDB, 1994d, n. 69. "non rifiuta in línea di principio di applicare il concetto di sacramento al ministero e all'ordinazione [...] com l'atto dell'ordinazione lo Spirito santo, comunicando la grazia, abilita l'ordinato a compiere il suo ministero." 
É nossa fé comum que a justificação é obra do Deus uno e trino. O Pai enviou seu Filho ao mundo para a salvação dos pecadores. A encarnação, a morte e a ressurreição de Cristo são fundamento e pressuposto da justificação. Por isso justificação significa que o próprio Cristo é nossa justiça, da qual nos tornamos participantes através do Espírito Santo, segundo a vontade do Pai. Confessamos juntos: somente por graça, na fé na obra salvífica de Cristo, e não por causa de nosso mérito, somos aceitos por Deus e recebemos o Espírito Santo, que nos renova os corações e nos capacita e chama para as boas obras ${ }^{59}$.

Mesmo sabendo que persistem divergências doutrinais entre as igrejas, há o reconhecimento mútuo dos elementos essenciais da fé cristã, o que forma um patrimônio comum, mesmo se esse tem expressões diferentes em cada tradição eclesial: "o fato que os reformadores tenham mantido sadiamente a continuidade com a igreja das origens é visto hoje com mais clareza e reforça a consciência da ecumenicidade e catolicidade da confissão luterana" ${ }^{60}$.

Assim, retomamos: se é possível reconhecer hoje em Lutero a fé que justifica, fé verdadeira, portanto, como isso pode ajudar a rever em nossos dias a excomunhão decretada no passado sob a acusação de fé falsa ou falta de fé? Relendo a vida do reformador, não se verifica a falta da fé professada pela igreja de então, mas dissensões teológicas na explicitação da fé. E a excomunhão não teve apenas razões teológicas. Parece-nos oportuno que, considerando o atual contexto positivo das relações entre a igreja católica e a luterana, no âmbito da comemoração conjunta dos 500 anos da Reforma aconteça um gesto de altíssimo nível simbólico que muito fortaleceria os esforços por reconciliação e comunhão na fé entre as duas igrejas: um gesto oficial, por parte do bispo de Roma, de retirada da excomunhão que foi imposta a Martinho Lutero em 03 de janeiro de 1521. Nossa sugestão segue o que propõe o diálogo católico-luterano: um ato de declaração da nulidade da excomunhão num contexto celebrativo, tratando-se de uma celebração de reconciliação, a qual assume um caráter penitencial pelos erros de uns e outros que levaram à divisão, às ofensas mútuas, à falta de caridade e também de ação de graças. ${ }^{61} \mathrm{O}$ ato de retirar a excomunhão, com um significado penitencial pela divisão e também como ação de graças e de louvor a Deus pelas atuais relações positivas entre as igrejas, seria uma privilegiada expressão da "fraternidade reencontrada" 62 , e teria um significado eclesial de valor inimaginável para a vida dos cristãos e das igrejas, fortalecendo a busca da comunhão na fé em Cristo e a comum responsabilidade no testemunho do seu evangelho no mundo.

${ }^{59}$ CICL, 1999, n. 15.

${ }^{60}$ CICL, 1994b, n. 54. "il fatto che i riformatori abbiano mantenuto saldamente la continuità com la chiesa dell' origini, viene visto oggi con più chiarezza e fafforza la consapevolezza dell'ecumenicità e cattolicità della confesione luterana."

${ }^{61}$ Cf. CICL, 1994b, n. 69.

${ }^{62}$ PAPA JOÃO PAULO II. Ut Unum Sint. São Paulo: Paulinas, 1995. n. 42. 


\section{Considerações finais}

Do refletido, parece-nos claro que não é teologicamente insustentável a possibilidade de um ato que indique o levantamento da excomunhão de Martinho Lutero. Essa possibilidade ganha sustentação na acolhida efetiva das convergências e consensos doutrinais resultantes do diálogo católico-luterano. Mas para isso não basta o trabalho dos teólogos. É preciso que as lideranças maiores das igrejas se disponham a fazê-lo. Os teólogos ajudam as igrejas a compreenderem o entendimento da complexidade da situação que levou à declaração da excomunhão no passado, do status quaestionis da divisão no presente, dos passos dados para a reaproximação, das consequências positivas do levantamento da excomunhão para o futuro da igreja. Uma vez esclarecidos esses pontos, aos líderes das igrejas cabe a responsabilidade de realizar atos oficiais de retirada da excomunhão.

\section{Referências}

A CONFISSÃO DE AUGSBURGO. São Leopoldo: Sinodal, 1999.

ARTIGOS DE ESMALCALDA. In: Enchiridion Oecumenicum. Bolonha: EDB, 1996. p. 603-610. DOCUMENTOS DO CONCÍLIO VATICANO II. São Paulo: Paulus, 2007.

CONGAR, Yves. Lutero, la Fede, la Riforma. Brescia: Morcelliana, 1984.

COMISSÃO INTERNACIONAL CATÓLICA LUTERANA. Do Conflito à Comunhão. Comemoração conjunta Católico-Luterana da Reforma em 2017. São Leopoldo: Sinodal; Brasília: CNBB, 2015.

Martin Lutero testimone di Gesù Cristo. In: Enchiridion Oecumenicum. Bolonha: EDB, 1994a. v. 1, p. 743-751. $\overline{752-830 .}$.

. L'unità davani a noi. In: Enchiridion Oecumenicum. Bolonha: EDB, 1994b. v. 1, p. $\overline{589-653 .}$.

La cena del Signore. In: Enchiridion Oecumenicum. Bolonha: EDB, 1994c. v. 1, p. p. 654-692.

Vie verso la comunione. In: Enchiridion Oecumenicum. Bolonha: EDB, 1994d. v. 1, LUTERO, Martinho. Discurso pronunciado na Dieta de Worms - Testemunho. In: VV.AA. Martin Luther, 450 ans de Réforme. Internationes, 1967. p. 52-56.

. Debate sobre a Teologia Escolástica (1517). In: LUTERO, Martinho. Obras Selecionadas.

São Leopoldo: Sinodal; Porto Alegre: Concordia, 1987. v. 1, p. 13-20.

Do Cativeiro Babilônico da Igreja. In: LUTERO, Martinho. Obras Selecionadas. São

Leopoldo: Sinodal; Porto Alegre: Concordia, 1989. v. 2, p. 341-424.

. Um Sermão sobre o Venerabilíssimo Sacramento do Santo e Verdadeiro Corpo de Cristo

e sobre as Irmandades (1519). In: LUTERO, Martinho. Obras Selecionadas. São Leopoldo:

Sinodal; Porto Alegre: Concordia, 1987. v. 1, p. 425-446.

. Das Boas Obras (1520). In: LUTERO, Martinho. Obras Selecionadas. São Leopoldo:

Sinodal; Porto Alegre: Concordia, 1989. v. 2, p. 97-170.

. A respeito do papado em Roma contra o Celebérrimo Romanista de Leipzig. In: LU-

TERO, Martinho. Obras Selecionadas. São Leopoldo: Sinodal; Porto Alegre: Concordia, 1989. v. 2, p. 197-238. 
LUTERO, Martinho. À Nobreza Cristã da Nação Alemã, acerca da Melhoria do Estamento cristão. In: LUTERO, Martinho. Obras Selecionadas. São Leopoldo: Sinodal; Porto Alegre: Concordia, 1989. v. 2, p. 277-340.

. Tratado de Martinho Lutero sobre a Liberdade Cristã. In: LUTERO, Martinho. Obras Selecionadas. São Leopoldo: Sinodal; Porto Alegre: Concordia, 1989. v. 2, p. 435-460.

. Dos Concílios e da Igreja. In: LUTERO, Martinho. Obras Selecionadas. São Leopoldo: Sinodal; Porto Alegre: Concordia, 1992. v. 3, p. 300-432.

Explicações do Debate sobre o Valor das Indulgências. Tese 89. In: LUTERO, Martinho. Obras Selecionadas. São Leopoldo: Sinodal; Porto Alegre: Concordia, 1987. v. 1, p. 55-190.

Martinho Lutero saúda Leão X, Pontífice Romano, em Cristo Jesus, nosso Senhor.

Amém. In: LUTERO, Martinho. Obras Selecionadas. São Leopoldo: Sinodal; Porto Alegre: Concordia, 1989. v. 2, p. 426-433.

MANCUSO, Vito. A excomunhão como arma contra a heresia criminosa. Revista IHU-Online. Disponível em: $<$ http://www.ihu.unisinos.br/noticias/532584-a-excomunhao-como-arma-contra-a-heresia-criminosa-artigo-de-vito-mancuso>. Acesso em: 09 ago. 2016.

MICHAELIS, Wilhelm. Controvérsias sobre a anulação da excomunhão. In: Concilium, v. 8, p. 95-110, 1976.

PAPA BENTO XVI. Discurso aos representantes do Conselho da Igreja Evangélica na Alemanha, em 23/09/2011. Disponível em: <http://w2.vatican.va/content/benedict-xvi/pt/speeches/2011/ september/documents/hf_ben-xvi_spe_20110923_evangelical-church-erfurt.html $>$. Acesso: 09 ago. 2016.

PAPA FRANCISCO. Entrevista concedida no avião quando retornava de sua visita pastoral à Armênia, em junho de 2016. Disponível em: <http://www.ihu.unisinos.br/556972-qas-intencoes-de-lutero-nao-estavam-equivocadasq-a-opiniao-dos-protestantes>. Acesso: 05 ago. 2016.

. Discurso à delegação ecumênica da Igreja Evangélica na Alemanha: Disponível em:

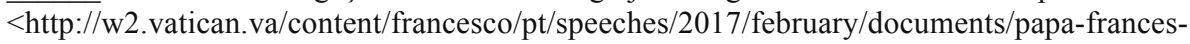
co_20170206_chiesa-evangelica.html>. Acesso em: 23 fev. 2017.

PAPA JOÃO PAULO II. Ut Unum Sint. São Paulo: Paulinas, 1995.

PAPA LEÃO X. Bulla Exsurge Domine. In; DENZINGER, Heinrich; HÜNERMANN, Peter. Enchiridion Symbolorum. Definitionum et declarationum de rebus fidei et morum. Bolonha: EDB, 1996. p. 627-635.

STAUFFER, Richard. La Reforma. Barcelona: Oikos; Tau Ediciones, 1974.

WILLEBRANDES, Johannes. Conferência na V Assembleia da Federação Luterana Mundial. In: La documentation Catholique, n. 1569, p. 761-767, 06/09/1970. 